\title{
Belemnites from the Lower Jurassic of East Greenland and their biostratigraphical and biogeographical significance
}

\author{
PETER DOYLE
}

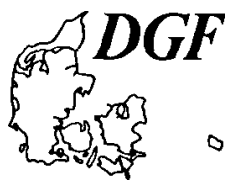

\begin{abstract}
Doyle, P.: Belemnites from the Lower Jurassic of East Greenland and their biostratigraphical and biogeographical significance. Bull. geol. Soc. Denmark, Vol. 39, pp. 123-141. Copenhagen, December 20th, 1991. https://doi.org/10.37570/bgsd-1991-39-04

Belemnites collected in the 1920s from the Lower Jurassic Neill Klinter Formation of East Greenland are described for the first time. Two belemnite faunas are recognised. The Rævekløft Member yielded Nannobelus, Pseudohastites, Passaloteuthis?, Gastrobelus? and a hastitid, giving an age of the Lower Pliensbachian Uptonia jamesoni to Prodactylioceras davoei zones for the molluscan-rich lower faunal division. The Ostreaelv Member yielded Parapassaloteuthis, Acrocoelites (Toarcibelus), A. (Odontobelus), Simpsonibelus and "Parabrachybeus" representative of a Toarcian Hildoceras bifrons to Haugia variabilis Zone age as previously determined. However, the presence of Parapassaloteuthis gives a oldest age of at least Dactylioceras commune Subzone, with a loose specimen of a possible juvenile Acrocoelites trisulculosus suggesting that the Ostreaelv Member may range into the Harpoceras falciferum Zone. The Pliensbachian species are identical to those from western Europe and are the most northerly representatives of their taxa. The Toarcian species have closest affinity to those of northwest Europe rather than the distinct and endemic Siberian Toarcian belemnite fauna which arose at this time.
\end{abstract}

Peter Doyle, School of Earth Sciences, Thames Polytechnic, Walburgh House, Bigland Street, London E1 2NG England. March 20th, 1991.

During the 1926-27 Danish expedition to East Greenland, Alfred Rosenkrantz studied in detail for the first time the Lower Jurassic deposits of Jameson Land. Extensive collections of the rich fossil invertebrate fauna were made by Rosenkrantz, and were listed in his subsequent stratigraphical publications (Rosenkrantz, 1934, 1942). However, of these specimens, only two crustacean species (Glyphaea rosenkrantzi van Straelen, 1929, Glyphaea sp.) and one bivalve (Velata hartzi Rosenkrantz, 1956) have been formally described (van Straelen, 1929; Rosenkrantz, 1956). The purpose of this paper therefore is to describe for the first time Lower Jurassic belemnites from Jameson Land and Liverpool Land, and to discuss their wider stratigraphical and biogeographical significance.

\section{Stratigraphy}

William Scoresby (1823) was first to record a stratigraphical succession in Neill Klinter (Neill's Cliffs) at Kap Stewart, which was dominated by sandstone with a marine fauna and underlain by coal-bearing strata. Subsequent macrofloral work determined a "Rhaeto-Liassic" age for the lower strata (Kap Stewart Formation), with the overlying marine strata (Neill Klinter Formation) yielding Early Pliensbachian and Toarcian fossils (see Rosenkrantz, 1934, p. 8). An early systematic study of the Lower Jurassic beds of southeastern Jameson Land and Liverpool Land is given in the papers of Rosenkrantz (1929, 1934, 1942). Since this seminal work, detailed aspects of the lithostratigraphy, sedimentology, ichnology and palaeogeographical significance of the Kap Stewart and Neill Klinter formations have been discussed by Surlyk et al. (1973, 1981), Sykes (1974a, b), Dam $(1989,1990)$ and Surlyk (1990).

Surlyk et al. $(1973,1981)$ and Surlyk (1977, $1978,1990)$ traced the development of the sediments within the East Greenland Jurassic basin. Taking a section from Jameson Land in the south to Store Koldewey $\emptyset$ in the north, a series of blocks active in the Jurassic can be recognised. In the Jameson Land-Scoresby Land area, the basin was downfaulted during Late Triassic to Early 


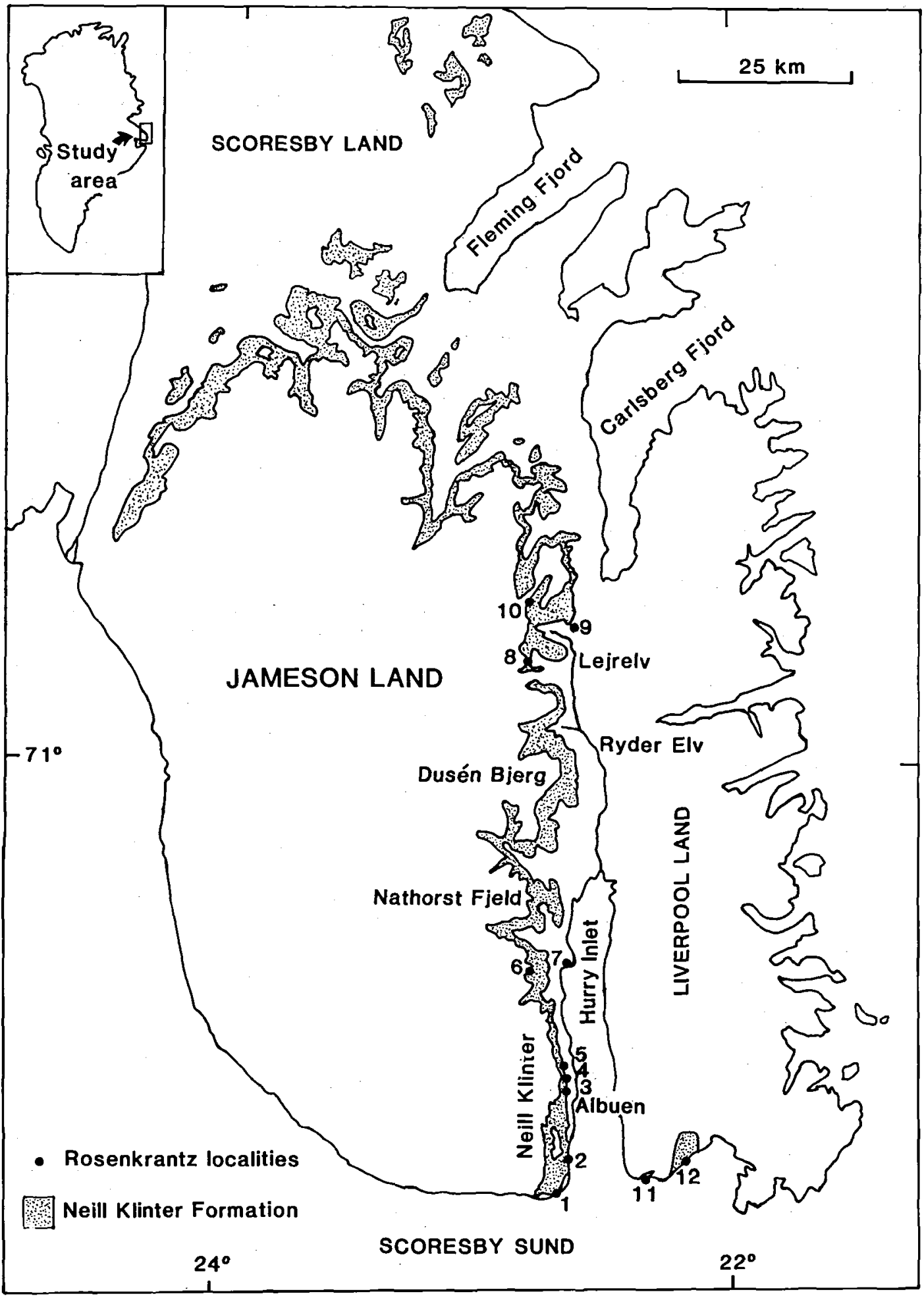

Text-fig. 1. Map of Jameson Land and Ljverpool Land, showing the outcrop of the Neill Klinter Formation (from Dam, 1989, fig. 1), and the approximate positions of the collecting localities of Rosenkrantz (1934). Key to localities: 1, Kap Stewart; 2, Trancrediakløft; 3, Goniomyakløft; 4, Vardekløft; 5, Astartekløft; 6, Harris Fjeld; 7, Constable Pynt; 8, Umingmakbjerg (Umimmak Fjeld); 9 , "mountain near Lejrelv" (unnamed); 10, Hjørnefjeldet; 11, Igtâjigmît (Igterajivit); 12, Kumait. 
Jurassic times allowing the accumulation of, first, non-marine alluvial sediments (Kap Stewart Formation, Rhaetian - Hettangian), followed by shallow marine deposits (Neill Klinter Formation, Pliensbachian - Toarcian) deposited in a Pliensbachian marine transgression. Lower Jurassic rocks are absent elsewhere in East Greenland. Subsequent deepening of this basin in later Jurassic times led to the accumulation of the shelf sediments of the Vardekløft Formation (Heinberg \& Birkelund, 1984) which caps the Lower Jurassic sediments in Neill Klinter.

Three members are presently recognised within the Neill Klinter Formation: Rævekløft Member (Lower Pliensbachian, Uptonia jamesoni and Prodactylioceras davoei zones have been recognised) (= Pecten limestone series of Rosenkrantz, 1934, p. 21); Gule Horn Member (largely lacking body fossils, possible Upper Pliensbachian); Ostreaelv Member (Toarcian, Hildoceras bifrons and "Lytoceras jurense" zones) (= Oyster bank series of Rosenkrantz, 1934, p. 21). The Rævekløft Member comprises coarse sandstones indicative of a high energy environment (see fig. 2 of Dam, 1990). The Ostreaelv Member comprises shelf and subaqueous shelf sandstones (fig. 2 of Dam, 1990) with uplift in the source area providing the coarse clastics. The intervening Gule Horn Member was probably deposited in a lower energy, shallow, possibly intertidal, environment (Surlyk et al., 1973; Dam, 1990).

The belemnites described below were recovered from the Rævekløft and Ostreaelv members, collected from southeastern Jameson Land and southern Liverpool Land. The specimens were accurately located by Rosenkrantz in his paper (Rosenkrantz, 1936), although using in some cases informal geographical names. These localities are given in fig. 1.

\section{Systematic descriptions}

All specimens are housed in the Geologisk $\mathrm{Mu}-$ seum, Copenhagen (GM), unless otherwise stated. The Geologisk Museum prefix MGUH denotes specimens in the type and figured collection. Other repositories: BMNH, Natural History Museum, London, England; GPIT, Geologisches und Paläontologisches Institut, Tübin- gen, Germany; OUM, Oxford University Museum, Oxford, England; WM, Whitby Museum, Whitby, England. For explanations of the terminology used below, see Doyle \& Kelly (1988) and Doyle (1990). The classification used below follows that given in the appendix to Doyle (in press). Approximate size (length) ranges are given by the terms small $(<50 \mathrm{~mm})$, medium (50-80 mm) and large (>80 mm). Measurements (in mm): L, total preserved length; 1 , length from protoconch to apex; Dv, dorsoventral diameter at the protoconch; DI, lateral diameter at the protoconch; Dvmax, maximum dorsoventral diameter; Dlmax, maximum lateral diameter; $x$, distance from apex to position of maximum inflation of the rostrum. For brevity, in most of the synonymies only the original valid description (denoted thus*), the most recent references (with full synonymy), and the citations of Rosenkrantz (1936) traceable to individual specimens still present in the Geologisk Museum are given. The symbol $v$ indicates the type and/or figured specimens have been examined. Subj., subjective synonym; obj., objective synonym. The approximate location of Rosenkrantz's collecting stations are given in text-fig. 1 .

Class Cephalopoda Cuvier, 1794

Subclass Coleoidea Bather, 1888

Order Belemnitida Zittel, 1895

Suborder Belemnitina Zittel, 1895

Family Belemnitidae d'Orbigny, 1845

Subfamily Belemnitinae d'Orbigny, 1845

Nannobelus Pavlow, 1913

(= Prototeuthis Lemoine, 1915, obj.; non Nannobelus Saks \& Nal'nyaeva, 1970)

Type species: Belemnites acutus Miller, 1826, by original designation.

Diagnosis: Small conical to cylindriconical Belemnitinae; outline and profile symmetrical, conical to cylindriconical; apex acute; transverse sections subquadrate to pyriform; apical grooves absent, though apex may bear striae; lateral lines two faint subparallel depressions on each flank; apical line ortholineate; phragmocone penetrates one-quarter to one-third rostrum. 

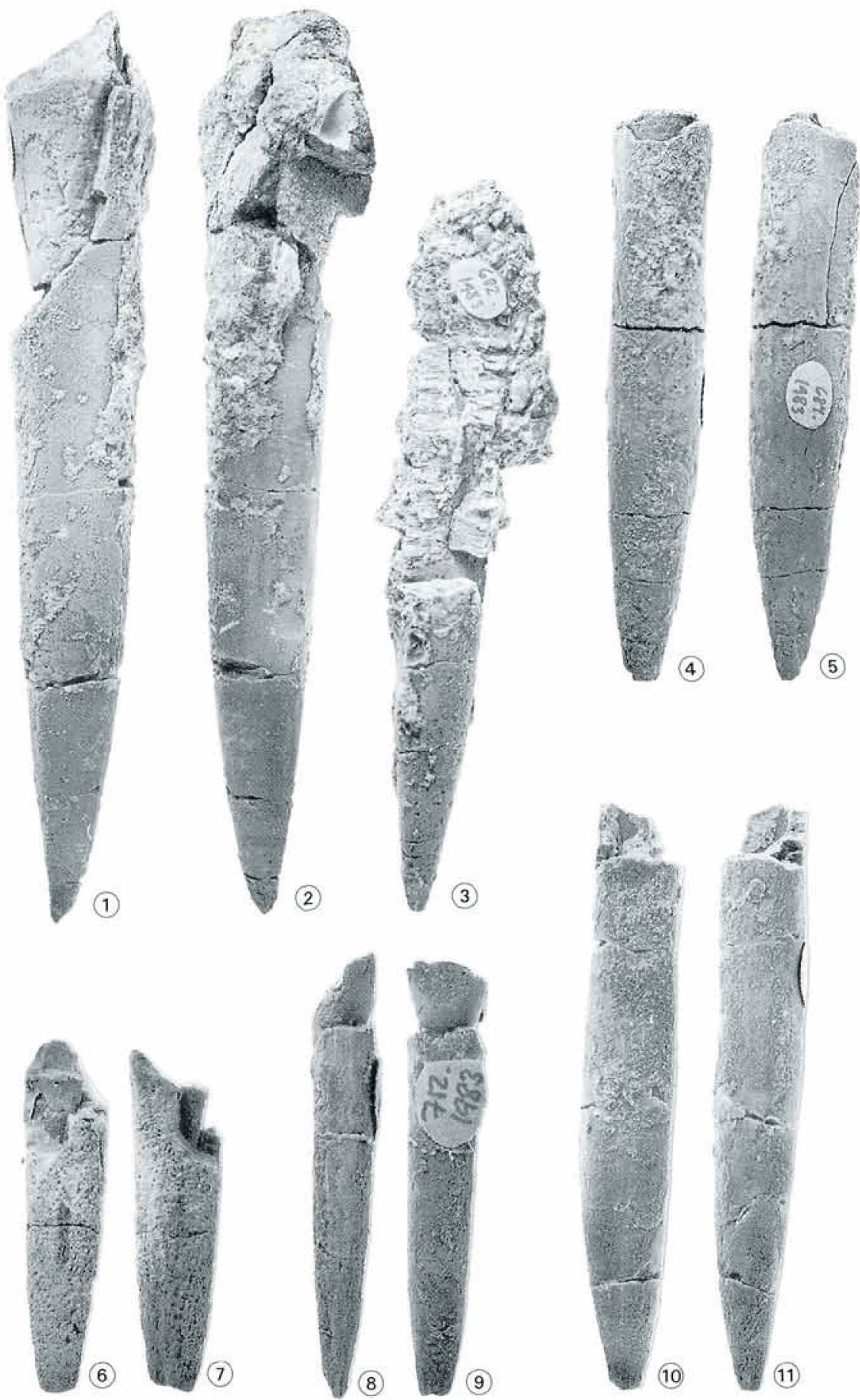

Plate 1. Figs 1-5, Pseudohastites apicicurvata (Blainville): 1, 2, ventral outline and profile, MGUH 20673, xI:3, profile, MGUH $20674, x 1 ; 4.5$, ventral outline and profile, MGUH 20675, x1. Figs 6, 7, Nannobelus sp., ventral outline and profile, MGUH 20672 , x1.5. Figs 8, 9. Nannobelus cf. alveolatus (Werner), ventral outline and profile, MGUH 20671, x1.5. Figs 10, 11, Passaloteuthis? sp., ventral outline and profile, MGUH 20676, x1. 
Range: Lower Sinemurian to Lower Pliensbachian of Europe (Britain, Germany, France, Italy, Denmark (Bornholm: GM 1879.742, N. acutus?), Sweden, Bulgaria, Czechoslovakia), Turkey, ?North Africa and East Greenland. Siberian "Nannobelus" of Toarcian age (Saks \& Nal'nyaeva, 1970) are endemic homeomorphs now grouped in the genus Arcobelus Saks, 1967 (Doyle, in press).

Nannobelus cf. alveolatus Werner, 1912 Pl. 1, figs 8, 9.

cf.*1912 Belemnites alveolatus Werner, p. 109, pl. X, figs. 2, 3 .

v1936 Prototeuthis cf. pennicillata (Dum.); Rosenkrantz, p. 30 (MGUH 20671).

cf.1951 Passaloteuthis alveolata (Werner); Troedsson, p. 242, pl. XXIV, figs 1, 2 only.

cf.1962a Belemnites alveolata Werner; Schwegler, p. 14, text-fig. 10 (most up-to-date reference).

Type specimens: Syntypes, the originals of Werner (1912, pl. X, figs. 2, 3), Lias $\beta$, Heiningen, Württemburg, Germany.

Material: Rævekløft Member, Jameson Land. Kap Stewart coast profile, bed a, MGUH 20671.

$\begin{array}{lcccc}\text { Dimensions: } & \text { L } & \text { I } & \text { Dv } & \text { DI } \\ \text { MGUH 20671 } & 39.3 & 25.2 & 6.4 & -\end{array}$

Description: A single, small, elongated ( $\mathrm{L}=39.3$ $\mathrm{mm})$ Nannobelus. The specimen is weathered on one flank, but is otherwise largely well-preserved. The profile is symmetrical and cylindriconical, but with the impression of slight "waist" developed in the alveolar region. The outline is symmetrical and cylindriconical. Transverse sections of the rostrum are pyriform with a broad venter. The apical region is devoid of grooves. The phragmocone penetrates up to one-third of the rostrum.

Remarks: The elongate form of this rostrum militates against a placement within either the acutely conical $N$. acutus (Miller) or the more robust $N$. engeli (Werner). In addition, although it resembles juvenile belemnitids of the genera
Passaloteuthis or Pseudohastites, this specimen may safely be assigned to the genus Nannobelus because it lacks any vestige of apical grooves. The specimen closely resembles $N$. alveolatus (Werner), which is equally elongated, but it is only tentatively assigned to this species because it does not possess a clear, subhastate form (e.g. Werner, 1912, pl. X, fig. 3).

The species Belemnites pennicillata Sowerby, as figured by Dumortier (1869, pl. IV, fig. 15), and cited by Rosenkrantz (1934), approaches this $N$. alveolatus in form, but is more robust than the present specimen with a slightly inflated venter and well-defined lateral lines.

\section{Nannobelus sp. \\ Pl. 1, figs 6, 7.}

Material: Ravekløft Member, Liverpool Land. Igtâjingmît (Igterajivit), MGUH 20672; Kumait, ?GM 1983.689.

Description and remarks: Of the two specimens, only one, MGUH 20672, can be definitely assigned to Nannobelus. The other, GM 1983. 689, represents a fragmentary rostrum with a penetrative phragmocone which cannot be assigned with certainty to this genus. Specimen MGUH 20672 is poorly preserved and slightly leached, but it presents a symmetrical and conical profile and outline, with what was probably an acute apex. The transverse sections are compressed (Dv:Dl 0.9). In general form, MGUH 20672 approaches $N$. acutus (Miller), but $N$. acutus is not commonly as compressed as this specimen (e.g. Doyle \& Marriotti, in press). In this way MGUH 20672 approaches the much larger species $N$. engeli (Werner, 1912, pl. X, fig. 4).

Pseudohastites Naef, 1922

(= ? Catateuthis Nal'nyaeva, 1967, subj.; Propassaloteuthis Riegraf, 1980, subj., non Pseudohastites Lang, 1928 (= new genus))

Type species: Belemnites scabrosus Simpson, 1866 , by original designation. The type specimen of the type species was recently refigured by Doyle (1990, text-fig. 13).

Diagnosis: Medium to large, elongate subcylindrical, cylindrical or subhastate Belemnitinae; 
outline symmetrical, cylindrical to cylindriconical; profile asymmetrical to symmetrical, subhastate to cylindrical; apex attenuated; transverse sections subquadrate to elliptical with flattened flanks; two short dorsolateral apical grooves restricted to apical region; apical striae common; lateral lines distinct, two elongate subparallel depressions separated by a ridge; apical line ortholineate to goniolineate; phragmocone penetrates one-third to one-quarter rostrum.

Range: Lower Pliensbachian to Lower Toarcian of Europe (Britain, Germany, France, Bulgaria, Czechoslovakia, Sweden, Portugal), Turkey, USSR (Siberia) and East Greenland.

Pseudohastites apicicurvata (Blainville, 1827)

P1. 1, figs 1-5 and 8, 9.

*1827 Belemnites apicicurvata de Blainville, p. 76 , pl. 2, fig. 6.

v1936 Passaloteuthis cf. apicurvata [sic] (de Blainville); Rosenkrantz, p. 55 (MGUH 20673); p. 58 (GM 1983.674); p. 59 (Passalotheutis cf. apicurvata [sic], MGUH 20674); p. 102 (GM 1983.705); p. 104 (GM 1983.705).

non1951 Passaloteuthis apicicurvata (Blainville); Troedsson, p. 243, pl. XXIV, figs 4, 5 (= ? Passaloteuthis ima Lang, 1928).

v1962b Belemnites apicicurvata Blainville; Schwegler, p. 123, text-fig. 18.

v1974 Belemnites paxillosus apicicurvata Blainville; Schuman p. 24, pl. 2, figs 9-13; pl. 3, figs 1.2 (full synonymy).

Type specimen: Neotype, selected Lang (1928, p. 205), BMNH C.29521, Bed 120d, Belemnite Marls (Tragophylloceras ibex Zone), Westhay Water, Dorset, England.

Material: Rævekløft Member, Jameson Land. Tancrediakløft, 140 m, GM 1983.699 (juvenile); Albuen, MGUH 20673; Goniomyakløft, GM 1983.674, 1983.675; mouth of Vardekløft, MGUH 20674; Constable Pynt, MGUH 20675; Astartekløft, ?GM 1983.692-1983.698 (fragments). Rævekløft Member, Liverpool Land. Kumait, GM 1983.686 (Juvenile), 1983.688, 1983.689, ?1983.690; Igtâjingmît (Igterajivit), GM 1983.705, 1983.706.

$\begin{array}{rrrrc}\text { Dimensions: } & \text { L } & 1 & \text { Dv } & \text { D1 } \\ \text { MGUH 20673 } & 121.8 & 65.7 & 16.2 & 15.7 \\ 20674 & 101.2 & 68.2 & 12.0 & - \\ 20675 & 78.2 & 59.7 & 13.3 & 12.7 \\ \text { GM 1983.675 } & 97.2 & 76.7 & 12.7 & -\end{array}$

Description: Medium to large, cylindriconical Pseudohastites. Outline symmetrical, cylindriconical, flanks weakly divergent adorally from an acute to attenuated apex, becoming parallel in the stem region. Profile broadly similar to outline, cylindriconical, with little inflation of venter. Transverse sections elliptical, but with lateral flattening. Apex exhibits only weakly developed dorsolateral apical grooves. Lateral lines where preserved, are in the form of a narrow ventrolateral depression bordered by a broader dorsolateral depression above. Phragmocone penetrates one-third of the rostrum. Juvenile elongate and cylindrical to weakly cylindriconical.

Remarks: This species is well-known in the Lower Pliensbachian of Europe and is characterised by its elongate and attenuated apex. The Greenland specimens closely resemble those figured by Lang (1928) and Schumann (1974) from Europe.

\section{Passaloteuthis Lissajous, 1915 \\ (= Holcoteuthis Stolley, 1919, subj.)}

Type species: Belemnites bruguieriana d'Orbigny, 1842 (= Belemnites bisulcata Blainville, 1827, subj.), by original designation.

Diagnosis: Medium to large, cylindrical to weakly subhastate Belemnitinae; outline symmetrical, cylindrical, cylindriconical to weakly subhastate; profile similar to outline, but inflated, asymmetrical to symmetrical; transverse sections subquadrate to circular; two short dorsolateral grooves restricted to apical region; short apical striae common; lateral lines indistinct, two weak subparallel depressions with weak ridge; apical line goniolineate; phragmocone penetrates one-third rostrum.

Range: Pliensbachian to Lower Toarcian of Europe (Britain, Germany, France, Italy, Sweden, Bulgaria, Czechoslovakia), Turkey, USSR, Chile and ?East Greenland. 

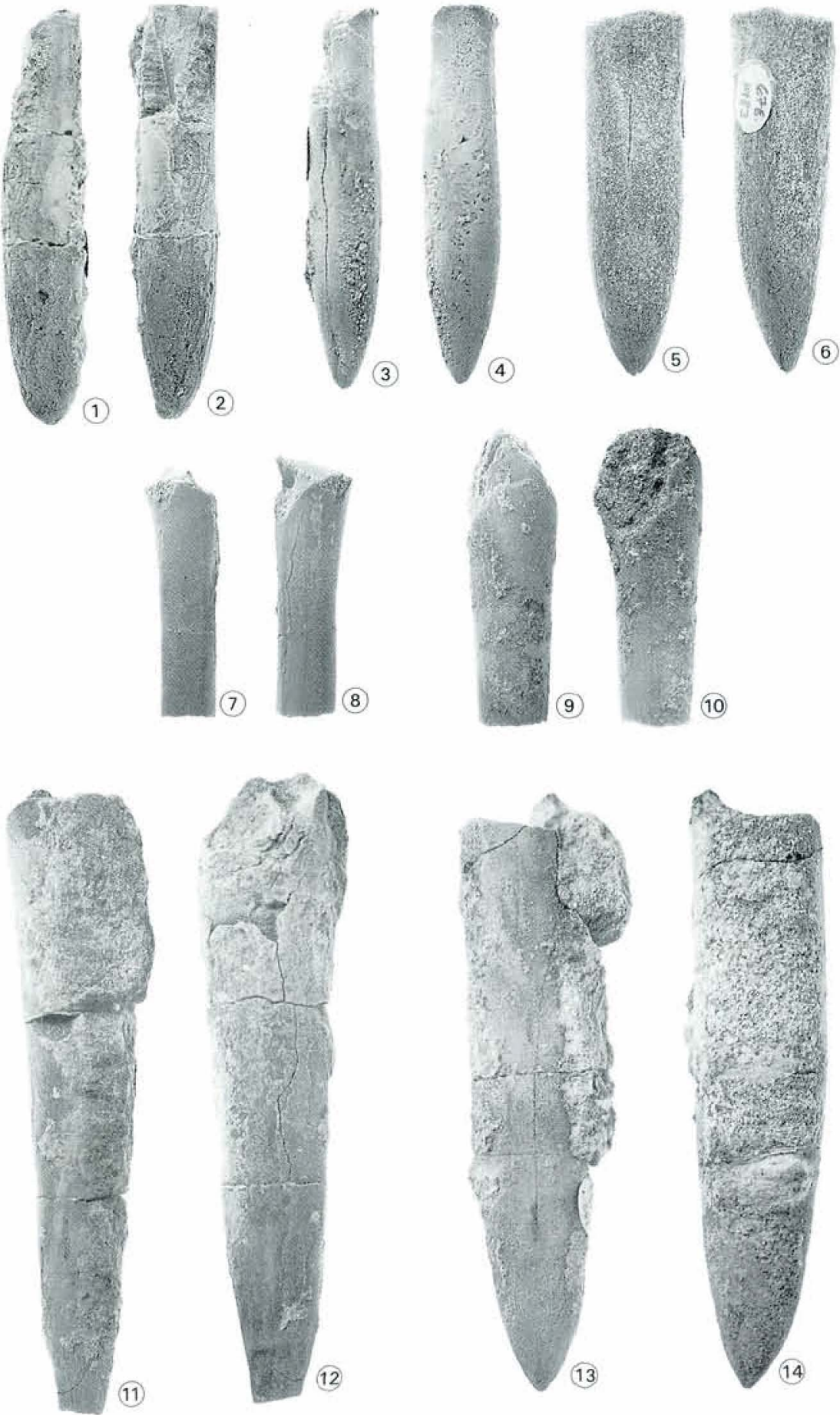

Plate 2. Figs 1, 2. Gasirobelus? aff. ventroplanus (Voltz), profile and ventral outline (apex distorted). MGUH 20688, x1. Figs 3, 4. Gastrobelus? sp., ventral outline and profile, MGUH 20689, x1. figs 5, 6, "Parabrachybelus" subaduncatus (Voltz), ventral outline and profile. MGUH 20687, x1. Figs 7-10, hastitid? indet.: 7. 8. ventral outline and profile. MGUH 20690. x1.5:9. 10. ventral outline and profile. MGUH 20691. x1.5. Figs 11. 12. Acrocoelites (Toarcibelus) ef, quenstedti (Oppel), ventral outline and profile, MGUH 20678, x1. Figs 13, 14, Parapassaloteuthis polita (Simpson), ventral outline and profile, MGUH 20677. xI. 
Passaloteuthis? sp. nov.

Pl. 1, figs 10, 11.

v1936 Passaloteuthis ef. apicurvata [sic] (de Blainville); Rosenkrantz, p. 104 (MGUH 20676).

Material: Rævekløft Member, Liverpool Land. Igtâjingmit (Igterajivit), MGUH 20676.

Dimensions: L $\quad 1 \quad$ Dv Dl Dvmax DImax $\quad x$ $\begin{array}{llllllll}\text { MGUH } 20676 & 81.0 & 59.9 & 11.6 & 11.8 & 11.9 & 13.0 & 36.4\end{array}$

Description: Medium sized, subhastate, depressed Passaloteuthis? The outline is symmetrical and subhastate with Dlmax almost at the midpoint of the rostrum (at $36.4 \mathrm{~mm}$ from the incomplete apex). The flanks weakly diverging adorally from the acute apex to this point, converging to the position at (1) before weakly diverging again. In profile the rostrum is almost symmetrical and cylindriconical, venter and dorsum weakly diverging from the acute apex. The transverse sections are depressed and almost subquadrate, but with a greater ventral width than dorsum. The apex bears two very faint dorsolateral apical grooves largely restricted to the apical tip. Lateral lines are present as a narrow, relatively incised, elongate dorsolateral depression with an indistinct ventrolateral depression beneath it. The phragmocone penetrates one-quarter of the rostrum.

Remarks: This rostrum is unusual in possessing a characteristically depressed transverse section. The form of cross-sections is a valuable specific character (Doyle \& Kelly, 1988) and, largely, depressed sections are unknown in the genus $P$ assaloteuthis. However, the overall form of the rostrum, its shape and grooves indicate close affinity to this genus. For these reasons, the specimen is only tentatively assigned to Passaloteuthis, and although possibly representative of a new species, the single specimen available militates against the formal erection of a new taxon.

\section{Parapassaloteuthis Riegraf, 1980}

Type species: Belemnites zieteni Mayer-Eymar, 1884 , by original designation.
Diagnosis: Small to large, robust cylindriconical to weak subhastate Belemnitinae; outline symmetrical, cylindriconical to weak subhastate; profile similar to outline, though asymmetrical; apex obtuse to mucronate, recurved;-transverse sections subquadrate to quadrate, uncompressed; two, weak to moderate, short dorsolateral grooves confined to apical region; lateral lines two parallel depressions, dorsal one broad and deep, extending from apical grooves, ventral one weak and indistinct; apical line cyrtolineate; phragmocone pentrates one-third to one-half rostrum.

Range: Upper Pliensbachian to Lower Toarcian of Europe (Britain, Germany, France, Czechoslovakia) and East Greenland.

Parapassaloteuthis polita (Simpson, 1866)

Pl. 2, figs 13, 14.

v*1866 Belemnites politus Simpson, p. 216.

v1936 Megateuthis sp.; Rosenkrantz, p. 62 (GM 1983.681); p. 83 (MGUH 20677).

v1990 Parapassaloteuthis polita (Simpson); Doyle, p. 27, pl. 5, figs 3-9 (full synonymy).

Type specimen: Lectotype, selected Doyle (1990, p. 27), WM 2047, Dactylioceras commune Subzone, High Whitby, North Yorkshire, England.

Material: Ostreaelv Member, Jameson Land. Vardekløft, 382 m, GM 1983.681; Nathorst Fjeld, 494 m, MGUH 20677.

$\begin{array}{lccccccc}\begin{array}{l}\text { Dimensions: } \\ \text { MGUH }\end{array} & \text { L } & \text { l } & \text { Dv } & \text { Dl } & \text { Dvmax Dlmax } & \text { x } \\ 20677 & 85.6 & 59.6 & 18.6 & 14.9 & 19.2 & 15.9 & 45.5\end{array}$

Description: Medium sized, cylindriconical to subhastate Parapassaloteuthis. Outline symmetrical to weakly subhastate, flanks moderately diverging from an acute but rounded apex to a point of maximum lateral diameter at the midpoint of the rostrum, weakly converging and then flaring adorally. Profile asymmetrical but cylindriconical with a slightly greater inflation of the venter. Transverse sections compressed, with flattened flanks and weakly curving venter and dorsum. No apical grooves developed; specimen 
surface too poorly preserved to observe lateral lines. The phragmocone penetrates one-third of the rostrum.

Remarks: This specimen is morphologically close to the type specimen of this species (WM 2047) from the Toarcian of North Yorkshire, England.

Subfamily Megateuthidinae Saks and $\mathrm{Nal}^{\text {' }}$ nyaeva, 1967 (nom. correct. ex. Megateuthinae Saks and Nal'nyaeva, 1967)

Acrocoelites Lissajous, 1915

Type species: Belemnites oxyconus Zieten, 1831, by original designation.

Diagnosis: Small and delicate to large and robust, conical, cylindriconical or cylindrical Megateuthidinae; outline symmetrical, conical, cylindriconical or cylindrical; profile asymmetrical, conical or cylindriconical, venter inflated; transverse sections compressed elliptical to subquadrate; apex characterised by two dorsolateral grooves and a single ventral groove; short epirostrum bearing striae may be present; lateral lines comprise two broad depressions separated by a weak ridge; phragmocone penetrates one-quarter to one-half rostrum; apical line goniolineate.

Range: Lower Toarcian to Aalenian of Europe (Britain, France, Germany, Portugal, Bulgaria, Czechoslovakia), Turkey, USSR (Siberia, Caucasus), North America (Alberta), Spitsbergen, East Greenland.

Subgenus Toarcibelus Riegraf, 1980

Type species: Belemnites quenstedti Oppel, 1856, by original designation.

Diagnosis: Large, robust, cylindriconical to cylindrical Acrocoelites; transverse sections subquadrate; apical grooves well-defined, ventral groove reduced in some species; apex striated; phragmocone penetrates one-quarter rostrum.

Range: Lower Toarcian to Aalenian of Europe (Britain, France, Germany, Bulgaria, Czechoslovakia), USSR (Siberia), East Greenland.
Acrocoelites (Toarcibelus) cf. quenstedti (Oppel, 1856)

. Pl. 2, figs 11, 12 .

cf."1856 Belemnites Quenstedti Oppel, p. 363.

v1936 Megateuthis rhenana (Oppel); Rosenkrantz, p. 89 (?GM 1983.713).

cf.v1969 Belemnites quenstedti Oppel; Schwegler, p. 188 , text-fig. 74 .

cf.v1990 Acrocoelites (Toarcibelus) quenstedti (Oppel); Doyle, p. 36, pl. 8, figs 3, 5-7 (full synonymy).

Type specimen: Neotype, selected Doyle (1990, p. 37), original of Schwegler (1969, text-fig. 74), GPIT (unregistered), Aalenian, Boll, Württemberg, Germany.

Material: Ostreaelv Member, Jameson Land. Mountain near Lejrelv, 630-660 m, MGUH 20678; Umnigmakberg (Umimmak Fjeld), 345$360 \mathrm{~m}$, ? GM 1983.713.

$\begin{array}{lrrrr}\begin{array}{l}\text { Dimensions: } \\ \text { MGUH }\end{array} & \text { L } & \text { l } & \text { Dv } & \text { Dl } \\ 20678 & 85.3 & 59.6 & 16.6 & 15.6\end{array}$

Description: Medium sized, cylindriconical Acrocoelites (Toarcibelus) Outline symmetrical, cylindriconical to acutely conical, flanks weakly diverging from an acute apex. Profile asymmetrical, cylindriconical with an almost flat dorsum and weakly inflated venter. Transverse sections compressed elliptical becoming laterally inflated adorally. Apex weathered in this specimen, but section exposed at the fractured apex indicates at least two dorsolateral apical grooves. Phragmocone penetrates and estimated one-third of the rostrum.

Remarks: In overall size and form this specimen approaches $A$. (T.) quenstedti, but its acute apex and almost conical outline allow only a tentative referal to this species.

\section{Subgenus Odontobelus Naef, 1922}

Type species: Belemnites pyramidalis Zieten, 1831 , by original designation.

Diagnosis: Medium, robust conical to cylindriconical Acrocoelites; venter inflated; apex acute 

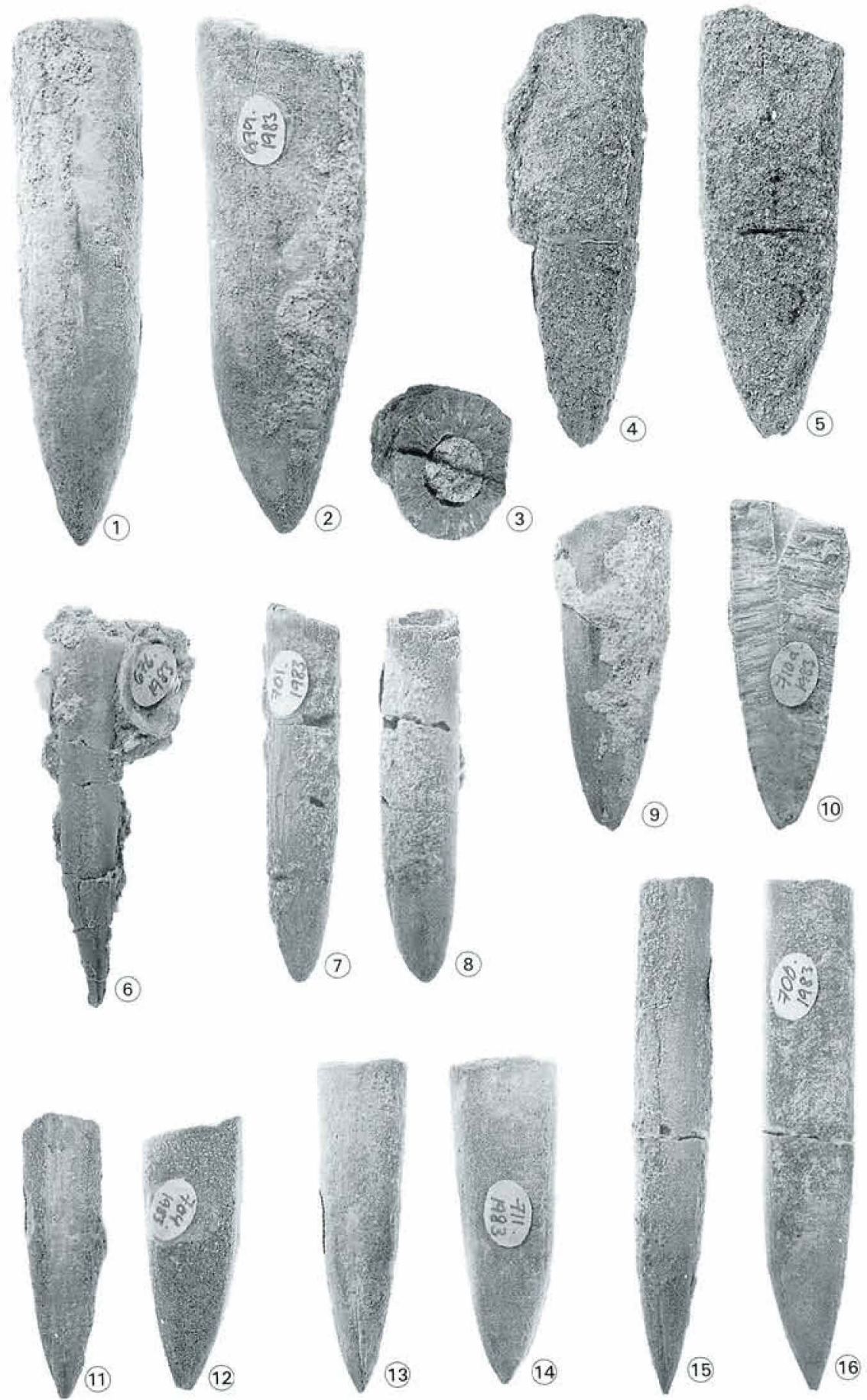

Plate 3. Figs $1-5,9,10$, Acrocoelites (Odontobelus) vulgaris (Young \& Bird): 1, 2, elongate form, ventral outline and profile, MGUH $20679, x 1 ; 3-5$, short form, alveolar section, ventral outline and profile, MGUH 20680, x1;9, 10, short form, profile and transverse section, MGUH 20681, x1. Fig. 6. Acrocoelites sp. juv. (juvenile Acrocoelites (Toarcibelus) trisulculosus (Simpson)?), profile, MGUH 20682, x1. Figs 7.8. Simpsonibelus expansus (Simpson), ventral outline and profile, MGUH 20683, x1. Figs 11-16, Simpsonibelus lentus (Simpson): 11, 12, ventral outline and profile, MGUH 20684, x1; 13, 14, ventral outline and profile, MGUH 20685, x1; 15, 16, ventral outline and profile, MGUH $20686, x 1$. 
to relatively obtuse; transverse sections compressed elliptical; ventral apical groove commonly reduced; phragmocone penetrates onehalf rostrum.

Range: Toarcian of Europe (Britain, Germany, France, Bulgaria, Czechoslovakia, Portugal), USSR (Siberia) and East Greenland.

Acrocoelites (Odontobelus) vulgaris (Young \& Bird, 1822)

Pl. 3, figs 1-5, 9, 10.

*1822 Belemnites vulgaris Young \& Bird, p. 258, pl. 14, fig. 1.

v1936 Megateuthis sp.; Rosenkrantz, p. 62 (MGUH 20680); p. 82 (MGUH 20679).

v1969 Belemnites tripartitus crassus Quenstedt; Schwegler, p. 199, text-fig. 82.

v1990 Acrocoelites (Odontobelus) vulgaris (Young \& Bird); Doyle, p. 44, pl. 11, figs $6-8$; pl. 13, figs 6, 7; pl. 14, figs 4-6; pl. 15, figs 2,3 (full synonymy).

Type specimen: Neotype, selected Doyle (1990, p. 44), OUM J. 15397, Alum Shales (Hildoceras bifrons Zone), Whitby, North Yorkshire, England.

Material: Ostreaelv Member, Jameson Land. Vardekløft, MGUH 20680; Nathorst Fjeld, MGUH 20679; Hjørnefjeldet, MGUH 20681.

$\begin{array}{lcccc}\begin{array}{l}\text { Dimensions: } \\ \text { MGUH }\end{array} & \text { L } & 1 & \text { Dv } & \text { Dl } \\ 20679 & 69.9 & 69.9 & 23.1 & 17.8 \\ 20680 & 57.1 & 44.2 & 19.8 & - \\ 20681 & 46.0 & 36.5 & 15.7 & 12.9\end{array}$

Discription: Medium sized, cylindriconical Odontobelus. Outline cylindriconical to cylindrical, with flanks diverging from an acute apex, becoming almost parallel in the stem region. Profile asymmetrical, venter inflated and conical to cylindriconical. Venter and dorsum inflated and arcuate, curving adapically to an acute apex. Transverse sections compressed elliptical. Surface of rostra poorly preserved, but in specimen MGUH 20681 at least two dorsolateral apical grooves are preserved. Phragmocone penetrates up to one-third of the rostrum, the apical line is goniolineate.

Remarks: In overall form, these belemnites approach $A$. (O.) vulgaris, although they can also be favourably compared with $A$. (O.) levidensis (Blake) (see Doyle, 1990, pl. 15, figs 4-7). However, the compressed transverse sections of these rostra, and their inflated profiles, indicates close affinity with $A$. (O.) vulgaris. Specimen MGUH 20679 is elongate relative to specimens MGUH 20680 and MGUH 20681. This phenomenon was also noted in $A$, (O.) vulgaris specimens from England by Doyle (1990, p. 45), who suggested the possibility of the two forms representing sexual dimorphs of a single biological species.

Acrocoelites sp. juv.

Pl. 3, fig. 6.

Material: Ostreaelv Member, Jameson Land. Harris Fjeld (loose block), MGUH 20682.

$\begin{array}{lcccc}\begin{array}{l}\text { Dimensions: } \\ \text { MGUH }\end{array} & \text { L } & 1 & \text { Dv } & \text { DI } \\ 20682 & 55.1 & 27.6 & 8.3 & 7.5\end{array}$

Discussion: The single specimen is representative of a juvenile Acrocoelites, possible of the subgenus Toarcibelus. Only the left profile is wellpreserved in this specimen, the right profile being obscured by a coarse sandstone matrix. The preserved flank exhibits an acutely conical rostrum with an attenuated apex. The outline can be interpreted as cylindriconical in form. The profile exhibits a well-developed dorsolateral apical groove with striations. Lateral lines are indistinct, but comprise a ventrolateral flattening with a barely discernable dorsolateral line above it.

Althoug incomplete, the morphology of this juvenile is reminiscent of juvenile specimens of the species Acrocoelites (Toarcibelus) trisulculosus (Simpson) (e.g. Doyle, 1990, pl. 9, fig. 5). The distinctive striated apical grooves and inflated venter are characteristic of the juvenile of this species.

Simpsonibelus Doyle, 1991

Type species: Belemnites expansus Simpson, 1855 , by original designation. 
Diagnosis: Small to medium, hastate to subhastate Megateuthidinae; outline symmetrical, hastate to subhastate; profile asymmetrical, arched, hastate; position of maximum inflation in stem third of rostrum; apex acute to attenuated; transverse sections depressed to compressed, subquadrate in alveolar region, rounded adapically; well-defined ventral groove restricted to apex, broadening adorally, two less distinct dorsolateral apical grooves also present; short, mid-dorsal groove may be present, not attaining anterior border, lacks splitting surface; lateral lines two parallel narrow depressions separated by weak to moderate ridge; apical line cyrtolineate; phragmocone penetrates one-quarter to one-fifth rostrum.

Range: Toarcian of Europe (Britain, Germany) and East Greenland.

Simpsonibelus expansus (Simpson, 1855)

Pl. 3, figs 7, 8 .

v*1855 Belemnites expansus Simpson. p. 31.

v1984 Dactyloteuthis (Catateuthis) aff. inaudita (Voronez); Riegraf et al., p. 161, pl. 12, fig. 9.

v1991 Simpsonibelus expansus (Simpson); Doyle, in press (full synonymy).

Type specimen: Holotype, WM 2685, Alum Shales, Peronoceras fibulatum - Catacoeloceras crassum subzones, Whitby, North Yorkshire, England.

Material: Ostreaelv Member, Jameson Land. Nathorst Fjeld, 543 m, MGUH 20683.

$\begin{array}{lccccccc}\begin{array}{l}\text { Dimensions: } \\ \text { MGUH }\end{array} & \text { L } & 1 & \text { DV } & \text { DI } & \text { Dvmax Dlmax } & x \\ 20683 & 53.3 & 36.7 & 10.9 & 10.3 & 11.0 & 10.3 & 29.0\end{array}$

Description: This specimen is representative of a small, weakly subhastate Simpsonibelus. The outline is symmetrical and barely subhastate with the position of maximum lateral inflation at the mid-point of the rostrum, and an acute apex. The profile is almost symmetrical, and subhastate, but with weakly inflated venter and rounded apex. The transverse sections are compressed elliptical in the apex and stem, becoming depressed in the alveolar region, with a flat dorsum in this posi- tion. The apex bears a well-defined ventral apical groove, and two less well-defined, shorter and broader dorsolateral apical grooves. The phragmocone penetrates approximately one third of the rostrum, and the apical line is strongly cyrtolineate.

Remarks: Although the compressed sections in the apical and stem regions of this specimen are uncommon in British representatives of this species (Doyle, 1991), the depressed alveolar section and short robust form distinguishes it from Simpsonibelus lentus (Simpson).

Simpsonibelus lentus (Simpson, 1855)

Pl. 3, figs 11-16.

v*1855 Belemnites lentus Simpson, p. 34.

v1936 Megateuthis cf. quenstedti (Oppel); Rosenkrantz, p. 93 MGUH 20685).

v1984 Dactyloteuthis (Catateuthis) inaudita (Voronez); Riegraf et al., p. 159, pl. 12, figs 5-8.

v1991 Simpsonibelus lentus (Simpson); Doyle, in press (full synonymy).

Type specimen: Holotype, WM 54, Alum Shales, Hildoceras bifrons Zone, Whitby, North Yorkshire, England.

Material: Ostreaelv Member, Jameson Land. Nathorst Fjeld, 543 m, MGUH 20686, MGUH 20684; Hjørnefjeldet, loc. 5, 320-425 m, MGUH 20685.

\begin{tabular}{|c|c|c|c|c|c|}
\hline $\begin{array}{l}\text { Dimensions: } \\
\text { MGUH }\end{array}$ & $\mathbf{L}$ & 1 & Dv & Dl & Dvmax Dlmax \\
\hline & 9.1 & 3.7 & 12. & 10. & 12.8 \\
\hline
\end{tabular}

Description: Medium sized, cylindrical to subhastate Simpsonibelus. Of the three specimens, only MGUH 20686 is preserved with apex, stem, and a portion of the alveolar region, and the description is based on this rostrum. Specimens MGUH 20684 and MGUH 20685 comprise only apical regions. Outline symmetrical, barely subhastate to cylindrical with flanks diverging from an acute apex only in the apical region. Profile asymmetrical, with an inflated venter, and barely subhastate, the maximum dorsoventral diameter in the adapical portion of the stem region. Transverse sections very compressed and elliptical for 
the length of the rostrum. Apex characterised by a well-defined ventral apical groove and two less well-defined dorsolateral grooves. The flanks are too abraded to reveal lateral lines. The alveolus penetrates an estimated one-quarter of the rostrum, and the apical line is cyrtolineate.

Remarks: The form of the three specimens, despite their imperfection, matches closely that of the type specimen (WM 54) from the Toarcian of the North Yorkshire, England.

\section{“Parabrachybelus” Riegraf, 1980}

Type species: Belemnites subaduncatus Voltz, 1830 , by original designation.

Discussion: This taxon was formally erected, as a subgenus of Brachybelus Naef, by Riegraf (1980) to contain the type species, following the discussion of its taxonomic position by Schwegler (1971, p. 100). In his discussion, Schwegler illustrated the overall Passaloteuthis-like morphology of Belemnites subaduncatus, comparing it with older Jurassic species of Pseudohastites. However, both Schwegler (1971) and Riegraf (1980) concluded that Belemnites subaduncatus was closely related to the genus Brachybelus (a junior homonym of Brachybelus Stål, Insecta, replacement name Brevibelus Doyle, 1991). Schwegler (1971) indicated that flattening of the flanks and excentricity of the alveolus allied $B$. subaduncatus with that genus, while Riegraf (1980) pointed to the apparent "furchenlose" (groove-less) condition of the apex as a valuable character. The present specimen described below, which is close to the original of Voltz (1830, pl. III, fig. 2), has relatively well-developed grooves, unknown in Brevibelus (see Doyle 1991), and any similarity in crosssectional form and excentricity of the apical line is not sufficient to ally $B$. subaduncatus with this genus.

Thus, as Schwegler (1971) has already noted, the true affinity of $B$. subaduncatus is ellusive. The grooves and form of the apex ally it with both Passaloteuthis Lissajous (PliensbachianLower Toarcian) and Megateuthis Bayle (Upper Toarcian-Bajocian). Schwegler (1971) suggests that the presence in some specimens of an apparent ventral apical groove was proof that it was closely related to Acrocoelites. The same kind of grooves also occur in the genus Passaloteuthis (e.g. Riegraf et al., 1984), but are probably not of great value in taxonomy given their transitory nature. What is clear from the foregoing discussion, is that Belemnites subaduncatus is not closely related to Brevibelus. Therefore, given that the present study rests on a single imperfect specimen, as a contingency "Parabrachybelus" is tentatively employed here as a nominal genus, more related in form to the genus Megateuthis than to Brevibelus. Confirmation of the status of "Parabrachybelus" will rest with a study of a more comprehensive collection of representatives of the type species.

\section{"Parabrachybelus" subaduncatus (Voltz, 1830) P1. 2, figs 5, 6.}

*1830 Belemnites subaduncatus Voltz; p. 48, pl. III, fig. 2.

1830 Belemnites subaduncatus Voltz; Zieten, p. 27, pl. XXI, fig. 4

1902 Belemnites subaduncatus Voltz; Janensch, p. 124, pl. XII, fig. 5 (non fig. $6=$ ?Megateuthis rhenana (Oppel)).

v1936 cf.Passaloteuthis subaduncata (Voltz); Rosenkrantz, p. 84 (MGUH 20687).

v1971 Belemnites subaduncatus Voltz; Schwegler, p. 100, text-fig. 109.

v1980 Brachybelus (Parabrachybelus) subaduncatus (Voltz); Riegraf, p. 152.

Type specimens: The original specimens of Voltz (1830) have been destroyed by fire (M. Wolf, pers comm. 1983). A neotype should be selected for this species, but this action is not appropriate in the present paper.

Material: Ostreaelv Member, Jameson Land. Nathorst Fjeld, 543 m, MGUH 20687.

Remarks: A single specimen comprising a fragment of an apical region $(L=48.7)$ of an apparently cylindrical or cylindriconical rostrum. From the fragment preserved, the outline appears cylindrical with flanks becoming parallel rapidly from the apex, while the profile appears more cylindriconical, with an acute and slightly recurved apex in this view. The transverse section at the fractured, adoral, end of the specimen is rounded subquadrate and compressed, typical of 
the species. The apex is also characteristic, bearing two short but incised dorsolateral apical grooves, but has well-defined apical striae on the venter and dorsum which are not recorded by other authors.

Family Hastitidae Naef, 1922

Gastrobelus Naef, 1922

Type species: Belemnites ventroplanus Voltz, 1830 , by original designation.

Discussion: This genus is relatively poorly known and defined. The type species possesses a distinctive morphology with a rounded, bulbous and yet depressed hastate rostrum which lacks apical grooves and has a characteristic flattened venter. These characters were highlighted in the original generic diagnosis of Naef $(1922$, p. 235). However, the concept of the genus was extended by Schumann (1974) who included within it the species Belemnites faseolus Dumortier and Belemnites virgatus Mayer. Both species contrast greatly with the type and are not easily contained within the genus, being distinctly compressed with acute apices and even apical grooves. More reasonable is the inclusion of Belemnites subdepressus Voltz, and Belemnites umbilicatus Blainville in the genus by Riegraf $(1980$, p. 145), as they are characterised by rounded apices and depressed transverse sections. This interpretation is followed here.

The inclusion of the genus Gastrobelus Naef in the family Hastitidae follows J. A. Jeletzky (pers comm. 1986) and is tentatively based on the hastate form of the rostrum and the rounded, grooveless apex. Further study, particularly of the lateral lines, is necessary to confirm this, but the two present specimens add little to the debate.

The belemnites described below are hastate with weakly depressed to compressed transverse sections and rounded apices. Gastrobelus? aff. ventroplanus is relatively characteristic of the genus, and although Gastrobelus? sp. is less so, it is included within it because it is unrepresentative of other hastitid genera.

Gastrobelus? aff. ventroplanus (Voltz, 1830)

Pl. 2, figs 1, 2. aff. ${ }^{* 1830}$ Belemnites ventroplanus Voltz, p. 40, pl. 1, fig. 10.

aff.1965 Belemnites ventroplanus Voltz i.e.S; Schwegler, p. 78, text-fig. 48.

aff.1974 Gastrobelus ventroplanus (Voltz); Schumann, p. 39, pl. 4, figs 10-13 (full synonymy).

Type specimens: The original specimens of Voltz (1830) have been destroyed by fire (M. Wolf, pers comm. 1983). A neotype should be selected for this species, but this action is not appropriate here.

Material: Rævekløft Member, Jameson Land. Mouth of Astartekløft, MGUH 20688.

Dimensions: L $\quad$ L Dv Dl Dvmax Dlmax $x$

$\begin{array}{llllllll}\text { MGUH } & & & & & & & \\ 20688 & 57.9 & 41.8 & 10.1 & 10.8 & 10.9 & 11.6 & 25.6\end{array}$

Description: Medium sized, hastate Gastrobelus?. Outline symmetrical, subhastate. Profile asymmetrical, suhastate with weakly inflated venter, Position of maximum inflation is in the central stem region of the rostrum. Apex obtuse and rounded, but with a pathological deformity in this specimen displacing the apex towards the right flank. Transverse sections depressed subcircular in the stem region becoming subquadrate in the alveolar region. There are no apical or alveolar grooves present. Although preserved in a coarse matrix, the left flank displays an elongate lateral depression corresponding to a portion of the lateral lines. The apical line is cyrtolineate. Phragmocone penetrates one-third of the rostrum.

Remarks: This specimen approaches $G$. ventroplanus in the bulbous form of its rostrum, and its subcircular transverse sections. It clearly has a cyrtolineate apical line and has a slightly depressed transverse section. However, the typical examples of this species (e.g. Voltz, 1830, pl. 1, fig. 10; Dumortier, 1869 , pl. 5, figs 5-7) have a much more pronounced ventral flattening, and therefore it can not be assigned to this species with any certainty.

Gastrobelus? sp.

Pl. 2, figs 3, 4 . 
Material: Rævekløft Member, Jameson Land. Dusén Bjerg (Dusén Fjeld), $550 \mathrm{~m}$, MGUH 20689.

$\begin{array}{lccccccc}\begin{array}{l}\text { Dimensions: } \\ \text { MGUH }\end{array} & \text { L } & 1 & \text { Dv } & \text { Dl } & \text { Dvmax } & \text { Dlmax } & x \\ 20689 & 52.3 & 36.9 & 10.1 & 9.2 & 10.7 & 10.1 & 23.8\end{array}$

Description: Medium sized hastate rostrum with affinities to Gastrobelus. Outline symmetrical, hastate with an acute apex. Profile similar to outline. Position of maximum inflation in stem third of rostrum. Transverse sections compressed and subquadrate for the length of the rostrum, being most quadrate in the alveolar region. The apex is smooth and devoid of grooves apart from a false "groove" eroded along a fracture plane. Mid-dorsal in the alveolar region is another groove. This could represent a primary alveolar groove, but it is eroded and could equally be an artifact of preservation. Lateral lines are difficult to determine, but the left flank has a pronounced flattening over most of its mid-part. The apical line is weakly cyrtolineate. The phragmocone penetrates one third of the rostrum.

Remarks: This specimen is not easily contained within the genus Gastrobelus. Particularly problematical are the acute apex and the compressed transverse section of this specimen. The pronounced hastate form is suggestive of Hastites, but the specimen is much too robust and squat to sanction assignment ot this genus. The genus Pleurobelus Naef is characterised by a compressed rostrum with a quadrate alveolar section, but without an acute apex. On balance the present specimen is assigned to Gastrobelus? because of its robust hastate form, although with due hesitancy.

Hastitid? indet.

PI. 2, figs 7-10.

v1936 Hastites? sp.; Rosenkrantz, p. 102 (MGUH 20690, 20691).

Material: Rævekløft Member, Liverpool Land. Kumait, MGUH 20690. 20691.

Discussion: Two fragments of the alveolar regions of hastitid? rostra are present in the collec- tion. Specimen MGUH 20690 is most like a hastitid, close in fact to the genus Hastites. It is slender and flares at the adoral-most part of the rostrum. The transverse sections are slightly compressed with flattened flanks. There is no evidence of the former presence of a bulbous stem apart from a slight flaring. Most important though is the presence of a pair of closely parallel lateral lines along each flank (Doppellinien), characteristic of some members of the Hastitidae and of the Belemnopseina in the younger Jurassic and Cretaceous. Specimen MGUH 20691 is more robust and compressed, but again displays the characteristic lateral lines.

\section{Stratigraphical significance of the belemnite fauna}

The original collections made by Rosenkrantz (1934) form the basis for most published age determinations of the Neill Klinter Formation, the fossiliferous horizons of the Rævekløft and Ostreaelv members providing the lower and upper control. This dating has been based upon the few specimens of ammonites that Rosenkrantz was able to obtain, along with extrapolation of lithotypes and the association of certain bivalve species.

Belemnites have been used in recent zonal schemes for parts of the Early Jurassic in other regions (Stoyanova-Vergilova, 1977; Doyle, 1990), and have considerable further potential as Jurassic biostratigraphical tools. Although there are relatively few belemnites surviving in Rosenkrantz's original collection, Dam (1989) records that they are not uncommon, in the Rævekløft Member at least, and their presence in the Neill Klinter Formation provides a further control on the dating of this sequence.

Raveklфft Member- Within the Rævekløft Member, Rosenkrantz (1934) found that fossils were restricted to certain fossiliferous levels punctuated by largely barren intervals. This has been confirmed by the observation of later workers (e.g. Dam, 1989, fig. 2). Rosenkrantz was able to identify two divisions: a lower, or Uptonia jamesoni division, with a diverse molluscan (mostly bivalve) fauna of 150 species, and an upper division containing approximately 20 molluscan spe- 


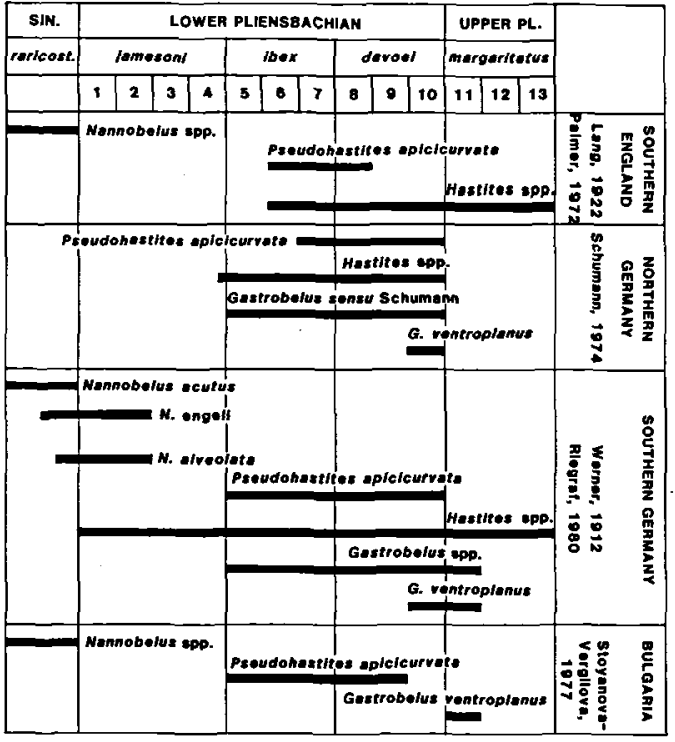

Text-fig. 2. European stratigraphical ranges of the belemnite species from the Ravekløft Member. Biostratigraphical zones from Dean et al. (1961). Sin., Sinemurian; Pl., Pliensbachian. Subzones: 1, Phricodoceras taylori; 2, Polymorphites polymorphus; 3, Platypleuroceras brevispina; 4, Uptonia jamesoni; 5 , Tropidoceras masseanum; 6, Acanthopleuroceras valdani; 7, Beaniceras luridum; 8, Aegoceras maculatum; 9, Aegoceras capricornus; 10, Oistoceras figulinum; 11, Amaltheus stokesi; 12 , Amaltheus subnododus; 13, Amaltheus gibbosus. For N. alveolata, read $N$. alveolatus.

cies, including rare specimens of Beaniceras and Aegoceras. Although Rosenkrantz considered that this upper division was representative of the Tragophylloceras ibex Zone, Callomon (1960, p. 261) later identified the Aegoceras as representative of the maculatum group, indicative of the lowermost Prodactylioceras davoei Zone. All the belemnites recovered from the Rævekløft Member by Rosenkrantz were apparently collected from the Uptonia jamesoni division.

The European stratigraphical ranges of Rævekløft Member belemnite species are given in textfig. 2. Nannobelus ranges in age from the Sinemurian to the earliest Pliensbachian, Uptonia jamesoni Zone, across Europe. In southern Germany, only the species $N$. alveolatus (Werner) and $N$. engeli (Werner) are known to extend into the Uptonia jamesoni Zone (Riegraf, 1980), and this is apparent in Scania also (Troedsson, 1951). In Turkey, $N$. acutus (Miller) has been recorded from an otherwise distinctive Uptonia jamesoni Zone fauna (Doyle \& Mariotti, in press). The specimens recorded from the Ravekløft Member include MGUH 20671, probably representative of $N$. alveolatus, from the lowest bed (bed a) of the coast profile at Kap Stewart. The stratigraphical range of this species in Germany (text-fig. 2) is consistent with a Uptonia jamesoni Zone age for at least the basal part of Rævekløft Member, although the paucity of specimens prevents firm conclusions.

The commonest belemnite in the Rævekløft Member appears to be Pseudohastites apicicurvata (Blainville) given the specimens still available, and the records given by Rosenkrantz (1934). Co-occuring in some sections are hastitids of the genera Gastrobelus? and hastitid indet. The distinctive $P$. apicicurvata and Gastrobelus? provide an important age control (text-fig. 2). In Germany (Schumann, 1974; Riegraf, 1980) and England (Lang, 1928; Palmer, 1972) these belemnites are unknown in rocks older than the Tragophylloceras ibex Zone (text-fig. 2), while for Bulgaria, Stoyanova-Vergilova (1977) designated a "Catateuthis apicicurvata" belemnite zone approximately equivalent to the Tragophylloceras ibex and Prodactylioceras davoei zones, succeeding two zones based on the occurrence of Nannobelus. The species Gastrobelus ventroplanus is known only from the Prodactylioceras davoei to Amaltheus margaritatus zones in Germany and Bulgaria (text-fig. 2). Činčurová (1979, p. 30) gave only an Early Pliensbachian age for the occurrence of $P$. apicicurvata in Czechoslovakia, but noted that it occurs above strata containing Nannobelus alveolatus and $N$. engeli. This is strong evidence that Rosenkrantz's Uptonia jamesoni bed has an age range of Uptonia jamesoni to at least Tragophylloceras ibex and possibly early Prodactylioceras davoei Zone age (text-fig. 2).

Ostreaelv Member- The Ostreaelv Member yielded a greater diversity of ammonites to Rosenkrantz (1934) than the older Rævekløft Member. These ammonites to Rosenkrantz (1934) than the older Rævekl $\varnothing \mathrm{ft}$ Member. These ammonites are typical of the Toarcian and comprise mainly species of Pseudolioceras with some Dactylioceras (including D. groenlandicum Rosenkrantz, figured but not described by Rosenkrantz, 1934, pl. 5, figs 4, 5). With the aid of these ammonites, Rosenkrantz (p. 118) distinguished Hildoceras bifrons, Grammoceras striatulum and Pleydellia aalensis zones (= Hildoceras bifrons, 


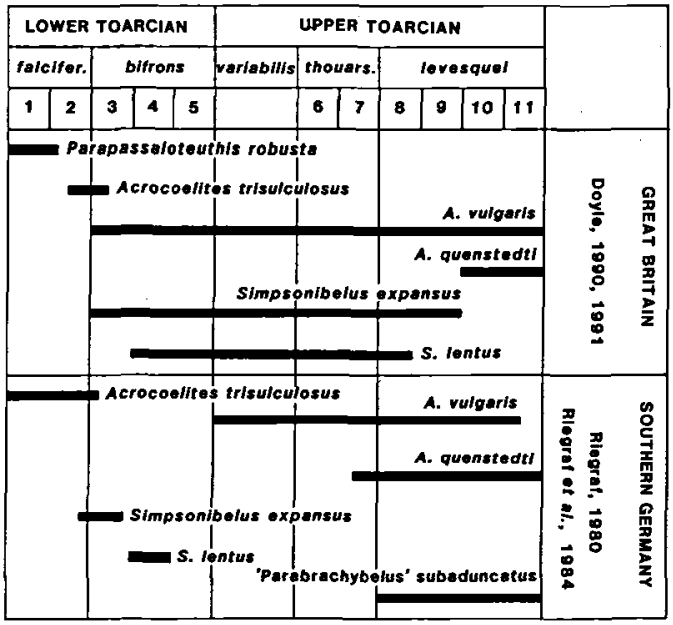

Text-fig. 3. European stratigraphical ranges of belemnite species from the Ostreaelv Member. Biostratigraphical zones from Dean et al. (1961) and Howarth (1978). Subzones: 1, Harpoceras exaratum; 2, Harpoceras falciferum; 3, Dactylioceras commune; 4, Peronoceras fibulatum; 5, Catacoeloceras crassum; 6, Grammoceras striatulum; 7, Pseudogrammoceras fallaciosum; 8, Phlyseogrammoceras dispansum; 9, Dumortieria levesquei; 10, Dumortieria moorei; 11, Pleydellia aalensis.

Grammoceras thouarsense and Dumortieria levesquei zones) based mainly on species of Pseudolioceras. Howarth (1978, p. 249) has summarised the correlation of Arctic successions using Pseudolioceras. Most interpretations, including that of Rosenkrantz, correlate the first major occurrence of diverse Pseudolioceras in the Arctic regions (with $P$. compactile (Simpson)) with the Grammoceras striatulum Subzone in Europe (e.g. Frebold, 1975, table 1). However, Howarth (1978) proposed that a better correlation was with the top of the Peronoceras fibulatum Subzone (Hildoceras bifrons Zone), as most "species" of Pseudolioceras could be accomodated within the single nominal species $P$. lythense (Young \& Bird). Given this interpretation, the Ostreaelv Member could be given a solely Early Toarcian (Hildoceras bifrons Zone) age, rather than an Early and Late Toarcian age as originally indicated by Rosenkrantz.

As for the Rævekløft Member, the belemnite fauna provides an additional control on the dating of the Ostreaelv Member. Belemnites are perhaps more diverse in the Toarcian than at any other time (e.g. Riegraf et al., 1984; Doyle, 1990, 1991), and recent work has proved their worth in Jurassic biostratigraphy (Stoyanova-Vergilova, 1977; Doyle, 1990). The ranges of Ostreaelv
Member species in Europe are given in textfig. 3. Palaeontologically, one of the fullest Toarcian sequences collected by Rosenkrantz (1936) in Jameson Land is that exposed in Nathorst Fjeld (Rosenkrantz, 1934, p. 80, pl. 12). At his locality 2 on Nathorst Fjeld, Rosenkrantz collected a specimen of Parapassaloteuthis polita at an altitude of $494 \mathrm{~m}$, and another of "Parabrachybelus" subaduncatus from $509 \mathrm{~m}$. These species have restricted ranges and are not known to be widespread throughout Europe. However, $P$. polita is only recorded from the latest Harpoceras falciferum Zone or earliest Hildoceras bifrons Zone (Dactylioceras commune Subzone) in Britain (Doyle, 1990), while "P. subaduncatus", so far recorded only from mainland Europe, has a range probably restricted to the Dumortieria levesquei Zone (Riegraf, 1980; text-fig. 3). This proves the presence in the Ostreaelv Member of strata of early Hildoceras bifrons Zone to $\mathrm{Du}$ mortieria levesquei Zone age, which is consistent with the ranges of the other belemnite species recorded from this member, Acrocoelites vulgaris, Simpsonibelus expansus, $S$. lentus and $A$. quenstedti (text-fig. 3). This in turn is broadly consistent with Rosenkrantz's (1934) observations.

Furthermore, the presence of Parapassaloteuthis polita in the Ostreaelv Member confirms that strata of Dactylioceras commune Subzone age (the oldest subzone of the Hildoceras bifrons Zone) are represented in southeastern Jameson Land. That still older strata may be present in the Ostreaelv Member is indicated by two separate lines of evidence. The presence of beds of $\mathrm{Har}$ poceras falciferum Zone age, is suggested by the single, possible juvenile Acrocoelites (Toarcibelus) trisulculosus (Simpson), a species restricted to the Harpoceras falciferum Zone in Europe (text-fig. 3). Beds of Dactylioceras tenuicostatum Zone age might also be present in the Ostreaelv Member. This observation is based on the presence of the ammonite Ostreaelv Member. This observation is based on the presence of the Dactylioceras groenlandicum Rosenkrantz aff. semicelatum (Simpson) recorded from the lower beds of the Ostreaelv Member at Nathorst Fjeld (Rosenkrantz, 1934). These beds did not apparently yield belemnites. It has been assumed that this Dactylioceras is representative of the younger Hildoceras bifrons Zone (Rosenkrantz, 1934), 
but it is the opinion of M. K. Howarth (pers comm. 1991) that this form is indeed close to Dactylioceras semicelatum (Simpson), a subzonal index for the top Dactylioceras tenuicostatum Zone in Europe (Howarth, 1973). This species has a broad range in morphology, including robust individuals resembling Catacoeloceras (Howarth, 1973, pl 7-9), and it is therefore feasible that the Dactylioceras-bearing beds of the Ostreaelv Member are older than first thought. Further study of the ammonite fauna, beyond the scope of this paper, is required for confirmation of these observations.

\section{Palaeobiogeographical significance of the belemnite fauna}

The significance of this fauna to belemnite biogeography has already been briefly touched upon elsewhere (Doyle, 1987, in press; Doyle \& Mariotti, in press), but for completeness a summary of its significance is given below.

The palaeogeography of Jameson Land in Early Jurassic times has been illustrated by Surlyk et al. (1981), Dam (1989, 1990) and Surlyk (1990). Its position was in a seaway that linked the European shelf areas with that of the boreal seas, and as has already been noted by Rosenkrantz (1934) the corresponding faunas are close to those of Europe. The Early Pliensbachian belemnite fauna of Jameson Land represents the most northerly true belemnite fauna known for this interval, as belemnites are not found in Siberian and other Arctic successions prior to the Toarcian (Saks \& Nal'nyaeva, 1970, 1975). The reason why belemnites were unable to penetrate past Greenland at this time is not clearly understood (Doyle, in press), but by the Toarcian, a time of marine transgression, they had successfully colonised the Siberian and other high Arctic basins (Saks \& Nal'nyaeva, 1970; Doyle, 1987, in press).

Both the Early Plienbachian and the Toarcian faunas are identical in specific content to those of Europe, and of the Toarcian fauna, only $A$. (T.) trisulculosus, possibly identified as a juvenile from Harris Fjeld, is present also in the Siberian basin, emphasising the endemicity of the Siberia Toarcian belemnite fauna at this time (Saks \& Nal'nyaeva, 1970, 1975; Doyle, in press).
Acknowledgements. I am grateful to Dr W. K. Christensen for the opportunity to study this belemnite fauna, for his hospitality during my visits to Copenhagen, and for arranging for the specimens to be photographed by Steen Jakobsen at the Geologisk Museum. Dr S. Watt kindly advised on Greenland place names, and I am grateful to Dr M. K. Howarth and Professors J. H. Callomon and D. T. Donovan for discussion. The manuscript was much improved by the attention of my two referees, Drs F. Surlyk and W. K. Christensen.

\section{Dansk sammendrag}

Belemnitter indsamlet $\mathrm{i} 1920 \mathrm{erne}$ fra den nedre jurassiske Neill Klinter Formation på $\emptyset$ stgrønland bliver her beskrevet for første gang.

Der findes to forskellige belemnit faunaer. Ravekløft Member indeholder Nannobelus, Pseudohastites, Passaloteuthis?, Gastrobelus? samt en hastitid form. Dette indicerer en alder svarende til nedre pliensbachien (Uptonia jamesoni til Prodaclioceras Zonerne) for den mollusk rige nedre fauna.

Ostreaelv Member indeholder Parapassalotheuthis, Acrocoelites (Toarcibelus), A. (Odontobelus), Simpsonibelus og "Parabrachybelus". Dette indicerer en toarcien alder (Hildoceras befrons til Haugia variabilis Zonen). Imidlertid antyder tilstedeværelsen af Parapassaloteuthis en ældste alder svarende til Dactylioceras commune Subzonen. Et løst eksemplar af en formodet juvenil Acrocoelites trisulculosus antyder at Ostreaelv Member kan række tidsmæssigt ind i Harpoceras falciferum Zonen.

Pliensbacien arterne er identiske med vesteuropæiske former og er de hidtil nordligst forekommende. Toarcien arterne har størst affinitet til vesteuropxiske former og adskiller sig fra den aldersmæssigt tilsvarende sibiriske belemnitfauna, der udvikles på dette tidspunkt og som er endemisk.

\section{References}

Blainville, M. H. de.1827. Mémoire sur les Bélemnites, considérées zoologiquement et géologiquement. 136 pp. Paris: Levrault.

Callomon, J. H. 1961: The Jurassic system in East Greenland. In Raasch, G. O. (edit.) Geology of the Arctic 1, 258-268. Toronto University Press.

Činčurová, E. 1979: Belemnity Liasu bradla Červený Kameň pri Podbieli. Př́rodov. Sb. Slov. Muz. 25, 29-61 (German summary).

Dam, G. 1989: Taxonomy of trace fossils from the shallow marine Lower Jurassic Neill Klinter Formation, East Greenland. Bull. geol. Soc. Denmark 38, 119-144.

Dam, G. 1990: Palaeonvironmental significance of trace fossils from the shallow marine Lower Jurassic Neill Klinter Formation, East Greenland. Palaeogeogr. Palaeoclimatol. $\mathrm{Pa}$ laeoecol. 79, 221-248.

Dean, W. T., Donovan, D. T. \& Howarth, M. K. 1961: The Liassic ammonite zones and subzones of north-west European province. Bull. Br. Mus. nat. Hist. (Geol.) 4, 437505.

Doyle, P. 1987: Lower Jurassic-Lower Cretaceous belemnite biogeography and the development of the Mesozoic Boreal Realm. Palaeogeogr., Palaeoclimatol., Palaeoecol. 61, 237-254.

Doyle, P. 1990: The British Toarcian (Lower Jurassic) belemnites. Part 1. Palaeontogr. Soc. (Monogr.) 49 pp. $17 \mathrm{pl}$. 
Doyle, P. 1991: The British Toarcian (Lower Jurassic) belemnites. Part 2. Palaeontogr. Soc. (Monogr.) in press.

Doyle, P. in press: Aspects of the distribution of Lower Jurassic belemnites. In Pallini, G. (edit.) Atti del III Convegno Internazionale, Fossili, Evoluzione, Ambiente, Pergola.

Doyle, P. \& Kelly, S. R. A. 1988: The Jurassic and Cretaceous belemnites of Kong Karls Land, Svalbard. Skr norske Polarinst. $189,77 \mathrm{pp}$.

Doyle, P. \& Mariotti, M. in press: Jurassic and Lower Cretaceous belemnites from north-western Anatolia (Turkey). Boll. Soc. geol. Ital.

Dumortier, E. 1869: Etudes paléontologiques sur les dépôts jurassiques du bassin du Rhône. 3. Lias Moyen. 348 pp. Paris.

Frebold, H. 1975: The Jurassic faunas of the Canadian arctic. Bull. geol. Surv. Can. $243.35 \mathrm{pp}$.

Heinberg, C. \& Birkelund, T. 1984: Trace-fossil assemblages and basin evolution of the Vardekløft Formation (Middle Jurassic, central East Greenland). J. Paleont. 58, 362-397.

Howarth, M. K. 1973: The stratigraphy and ammonite fauna of the Upper Liassic Grey Shales of the Yorkshire Coast. Bull Br. Mus. nat. Hist. (Geol.) 24, 237-277.

Howarth, M. K. 1978: The stratigraphy and ammonite fauna of the Upper Lias of Northamptonshire. Bull. Br. Mus. nat. Hist. (Geol.) 29, 235-288.

Janensch, W. 1902: Die Jurensisschicten des Elsass. Abh. geol. SpecKarte Els.-Loth. N. F. 5, 1-151.

Lang, W. D. 1928: The Belemnite Marls of Charmouth, a series in the Lias of the Dorset Coast. IV. The belemnites. $Q . J$. geol. Soc. Lond. 84, 196-222.

Miller, J. C. 1826: Observations on belemnites. Trans. geol. Soc. Lond., Second series 2, 45-62.

Naef, A. 1922: Die fossilen Tintenfische; eine paläozoologische monographie. 322 pp. Jena: Fischer.

Palmer, C. P. 1972: A revision of the zonal classification of the Lower Lias of the Dorset coast in South-West England. Newsl. Stratigr. 2, 45-54.

Riegraf, W. 1980: Revision der Belemniten des schwäbischen Jura. Teil 7, Palaeontographica A 169, 128-208.

Riegraf, W., Werner, G., \& Lörcher, F. 1984: Der Posidonienschiefer, Biostratigraphie, Fauna und Fazies des südwestdeutschen Untertoarciums (Lias E). 195 pp. Enke: Stuttgart.

Rosenkrantz, A. 1929: Preliminary account of the geology of the Scoresby Sound district. In Koch, L. The geology of East Greenland. Meddr. Grønland 73 (2), 133-154.

Rozenkrantz, A. 1934: The Lower Jurassic rocks of East Greenland. Meddr. Grønland 110 (1), 122 pp.

Rosenkrantz, A. 1942: The Lower Jurassic rocks of East Greenland II: The Mesozoic sediments of the Kap Hope area, southern Liverpool Land. Meddr. Gronland 110 (2), $56 \mathrm{pp}$.

Rosenkrantz, A. 1956: A large Velata from the Lower Jurassic of East Greenland. Meddr Dansk geol. Foren. 13, 79-84.

Saks, V. N. \& Nal'nyaeva, T. I. 1970: Early and Middle Jurassic belemnites of northern USSR. Nannobelinae, Passaloteuthinae and Hastitidae. Tr. Inst. Geol. Geofiz. Sib. Otd. $110,228 \mathrm{pp}$

Saks, V. N. \& Nal'nyaeva, T. I. 1975: Early and Middle Jurassic belemnites of northern USSR. Megateuthinae and Pseudodicoelitinae. $191 \mathrm{pp}$. Nauka: Leningrad.

Schuman, H. 1974: Die Belemniten des norddeutschen Lias gamma. Geol. Jb. A $12,35 \mathrm{pp}$.
Schwegler. E. 1962a: Revision der Belemniten des schwäbischen Jura. Teil 2. Palaeontographica A 118, 1-22.

Schwegler. E. 1962b: Revision der Belemniten des schwäbischen Jura. Teil 3. Palaeontographica A 120, 121-164.

Schwegler. E. 1965: Revision der Belemniten des schwäbischen Jura. Teil 4. Palaeontographica A 124, 75-115.

Schwegler. E. 1969: Revision der Belemniten des schwäbischen Jura. Teil 5. Palaeontographica A 132, 179-219.

Schwegler. E. 1971: Revision der Belemniten des schwäbischen Jura. Teil 6. Palaeontographica A 138, 81-129.

Scoresby, W. 1823: Journal of a voyage to the northern whalefishery. Edinburgh.

Simpson, M. 1855: The fossils of the Yorkshire Lias. $149 \mathrm{pp}$. London.

Simpson, M. 1866: Inferior Oolite, Lias, belemnites, etc., of the Yorkshire Coast. Geol. Nat. Hist. Rep., 1866, 215-216.

Stoyanova-Vergilova, M. 1977: An attempt for belemnite zonal subdivision of the Lower Jurassic sediments in Bularia. God, sof. Univ. Geol. Geog. Fak. 70, 161-192. (In Bulgarian, English summary).

Straelen, V. Van. 1929: Sur des Crustacées decapodes jurassiques du Groenland oriental. Bull. Acad. r. Belg. Cl. Sci. 5 sér. 25.

Surlyk, F. 1977: Stratigraphy, tectonics and palaeogeography of the Jurassic sediments of the areas north of Kong Oscars Fjord, East Greenland. Bull. Grønlands geol. Unders. 123, $56 \mathrm{pp}$.

Surlyk, F. 1978: Jurassic basin evolution of East Greenland. Nature 274, 130-133.

Surlyk, F. 1990: Timing, style and sedimentary evolution of Late Palaeozoic - Mesozoic extensional basins of East Greenland. In Hardmann, R. F. P. \& Brooks, J. (edit.) Tectonic events responsible for Britains oil and gas reserves. Geol. Soc. Sp. Publ. 55, 101-125.

Surlyk, F., Callomon, J. H., Bromley, R. G. \& Birkelund, T. 1973: Stratigraphy of the Jurassic-Lower Cretaceous sediments of Jameson Land and Scoresby Land, East Greenland. Bull. Gronlands geol. Unders. 101, $73 \mathrm{pp}$.

Surlyk, F, Clemmensen, L. B. \& Larsen, H. C. 1981: PostPalaeozoic evolution of the East Greenland continental margin. In Kerr, J. W. \& Ferguson, A. J. (edit.) Geology of the North Atlantic borderland. Can. Soc. Petrol. geol. Mem. 7, 611-645.

Sykes, R. M. 1974a: Sedimentological studies in southern Jameson Land, East Greenland. I. Fluviatile sequences in the Kap Stewart Formation (Rhaetic-Hettangian). Bull. geol. Soc. Denmark 23, 203-212.

Sykes, R. M. 1974b: Sedimentological studies in southern Jameson Land, East Greenland. II. Offshore-estuarine regressive series in the Neill Klinter Formation. Bull. geol. Soc. Denmark 23, 213-224.

Troedsson, G. T. 1951: On the Höganäs Series of Sweden (Rhaeto-Lias). Skr. Min. Pal. geol. Inst. Lund 7, 269 pp.

Voltz, M. 1830: Observations sur les Bélemnites. Mém. Soc. Hist. nat. Strasbourg 1, $70 \mathrm{pp}$.

Werner, E. 1912: 1912: Über die Belemniten des schwäbischen Lias und die mit ihnen verwandten Formen des Braunen Jura (Acoeli). Palaeontographica 59, 103-146.

Young, G. \& Bird, J. 1822: A geological survey of the Yorkshire Coast. 335 pp. Whitby.

Zieten, K. H. von. 1830-33: Die Versteinerungen Wurttembergs. 102 pp. Stuttgart. 